KINETIK, Vol.1, No.1, Mei 2016, Hal. 1-8

ISSN : 2503-2259,

E-ISSN : 2503-2267

\title{
Peningkatan Kualitas Evaluasi Mutu Akademik Universitas Muhammadiyah Malang melalui Sistem Informasi Mutu (SIMUTU)
}

\author{
Galih Wasis Wicaksono*1, Andi Al-Rizki ${ }^{2}$ \\ 1,2Universitas Muhammadiyah Malang \\ galih.w.w@umm.ac.id*
}

\begin{abstract}
Abstrak
Implementasi Sistem Penjaminan Mutu Internal (SPMI) di Universitas Muhammadiyah Malang (UMM) yang dilaksanakan oleh Badan Kendali Mutu Akademik, prinsip kerjanya mengacu pada siklus penetapan standar, pelaksanaan standar, evaluasi pelaksanaan standar, pengendalian standar dan peningkatan standar. Siklus penjaminan mutu internal tersebut menuntut kedinamisan sehingga mendorong pemanfaatan teknologi informasi sebagai tools dalam pelaksaannya. Sampai tahun 2016, UMM memiliki 43 dokumen mutu, dengan jumlah mahasiswa 35.466 orang mahasiswa dan jumlah dosen 614 orang dosen, yang tersebar di 55 program studi dan program profesi. Apabila seluruh dokumen mutu dilaksanakan secara manual mengikuti siklus SPMI, maka membutuhkan sumberdaya manusia, waktu dan biaya yang sangat besar. SIMUTU mampu meningkatkan jumlah evaluasi yang sebelumnya hanya 6 evaluasi setiap tahun dengan 4 target evaluasi, saat ini mampu melaksanakan 13 evaluasi setiap tahun dengan 6 target evaluasi. Prototype SIMUTU dikembangkan dengan pola desain Hierarchical Model View Controller. Pengujian fungsionalitas dengan automation test melalui testomato.com menunjukkan seluruh fitur sukses dijalankan.
\end{abstract}

Kata kunci: SIMUTU, SPMI, mutu

Abstract
Implementation of Internal Quality Assurance System (SPMI) in Universitas Muhammadiyah Malang (UMM) is conducted by the Academic Quality Assurance Bureau. The system was refer to the cycle of internal quality assurance composed of the determination of standards, the implementation of standards, the evaluation of implemented standards, the control of standards and the improvement of standards. The cycle of internal quality assurance requires a dynamically process. To encourage that, we use information technology as a tool. Until 2016, UMM has 43 documents on quality. In other hand, UMM has 35.466 students, 614 lecturers, spreads over 55 department and professional courses. If all of the quality standards must implemented following the cycles of SPMI, it would require a large of human resources, time and enormous costs. SIMUTU able to increase the number of evaluations that were previously only 6 evaluations every year, with four targets of evaluation. Now it able to perform 13 evaluations each year with six targets evaluation. SIMUTU developed with Hierarchical Model View Controller. Functionality testing with test automation through testomato.com shows all the features of a successful run.

Keywords: SIMUTU, SPMI, mutu

\section{Pendahuluan}

Perguruan Tinggi (PT) memiliki kewajiban untuk melaksanakan aktivitas penjaminan mutu secara otonom, sebagai bagian dari upaya meningkatkan sekaligus mengendalikan penyelenggaraan pendidikan tinggi yang berkualitas. Pelaksanaan penjaminan mutu secara internal oleh PT dilaksanakan secara sistemik melalui Sistem Penjaminan Mutu Internal (SPMI) yang diatur dalam Peraturan Menteri Pendidikan dan Kebudayaan Republik Indonesia No. 50 Tahun 2014. Prinsip kerja SPMI mengacu pada siklus penetapan standar PT, pelaksanaan standar PT, evaluasi standar PT, pengendalian standar PT dan peningkatan standar PT [1]. 
Implementasi SPMI di Universitas Muhammadiyah Malang (UMM) dilaksanakan oleh Badan Kendali Mutu Akademik (BKMA). Berdasarkan siklus SPMI, BKMA melakukan perancangan, penyusunan dan kemudian bersama pimpinan universitas melakukan penetapan standar mutu PT. Karakteristik standar mutu PT antara lain melampaui standar nasional pendidikan tinggi (SN Dikti) yang ditetapkan oleh pemerintah. Standar mutu PT yang telah ditetapkan kemudian dilaksanakan oleh semua PT. Standar mutu PT di UMM dilaksanakan oleh Dosen, sedangkan Program Studi, Laboratorium, Perpustakaan, dan Fakultas sebagai satuan organiasasi terkecil. Tahapan selanjutnya adalah evaluasi secara berkala oleh BKMA. Selanjutnya hasil evaluasi pelaksanaan standar mutu PT akan dikendalikan, pengendalian sangat bergantung pada hasil evaluasi. Tahapan terakhir adalah peningkatan standar mutu PT yang berarti melakukan perubahan terhadap standar mutu PT untuk memperoleh standar mutu yang lebih tinggi dibandingkan sebelumnya. Alur ini disebut juga dengan kaizen atau continuous quality improvement.

Siklus SPMI yang menuntut kedinamisan mendorong pemanfaatan teknologi informasi sebagai tools dalam pelaksaannya. Sebagai ilustrasi, UMM telah menentapkan 43 dokumen standar mutu PT, dengan jumlah mahasiswa 35.466 orang mahasiswa, jumlah dosen 614 orang dosen, yang tersebar di 55 program studi dan program profesi, sehingga apabila seluruh siklus SPMI dilaksanakan, maka akan membutuhkan sumberdaya manusia, waktu dan biaya yang sangat besar untuk mengelola aktivitas penjaminan mutu akademik di UMM. Penelitian ini memberikan solusi melalui pengembangan sistem informasi mutu (SIMUTU) sebagai upaya peningkatan kualitas evaluasi mutu akademik di UMM. Penelitian ini juga membatasi ruang lingkup penelitian hanya pada tahapan evaluasi dalam siklus SPMI.

Penelitian - penelitian terkait antara lain pengembangan perangkat lunak sistem penjaminan mutu hanya pada bidang sumber daya manusia [2]. Pengembangan aplikasi sistem informasi audit mutu internal, dengan target hasil tersedianya dokumen mutu. Sistem yang telah dikembangkan pada penelitian tersebut menyediakan fasilitas bagi auditor untuk dapat menambahkan pertanyaan berdasarkan klausal ISO 9001:2008, dengan fokus sistem hanya pada auditor [3]. Penelitian penjaminan mutu berbasis sistem informasi dengan memanfaatkan The Open Group Architecture Framework (TOGAF) Architecture Development Method (ADM), kontribusi penelitian ditujukan bagi Sekolah Menengah Kejuruan (SMK) [4]. Penelitian lainnya menggunakan pendekatan Throwaway Prototyping Development pada pengembangan sistem informasi penjaminan mutu dengan titik berat pada penyediaan dokumen borang akreditasi [5]. Keterbaruan dalam penelitian ini dapat dilihat pada substansi permasalahan kaizen dalam siklus SPMI yang dititik beratkan pada tahapan evaluasi pelaksanaan standar mutu PT. Karakteristik SPMI ialah peningkatan standar mutu PT dari waktu ke waktu. Hal tersebut tentunya berdampak pada pelaksanaan evaluasi pelaksanaan standar mutu PT yang terus berubah dan dinamis, sehingga SIMUTU menjadi solusi yang tepat untuk masalah tersebut.

SIMUTU dirancang dan dibangun pada teknologi berbasis web, sehingga dapat diakses secara online di semua platform. SIMUTU versi 1 dibangun dengan menggunakan pendekatan structural programming, dengan berbagai keterbatasan dalam lingkungan pengembangan sistem informasi. SIMUTU versi 2 yang menjadi obyek penelitian ini menggunakan pendekatan obyek oriented programming memanfaatkan framework php yakni codeigniter dengan pola desain hierarchical model view controller (HMVC). SIMUTU menggunakan database MySQL. Siklus pengembangan perangkat lunak yang digunakan ialah model prototyping. SIMUTU merupakan hasil reverse engineering atas SIMUTU versi 1, SIMUTU versi 1 memiliki fitur evaluasi yang dijelaskan pada Tabel 1 .

Tabel 1. Fitur evaluasi dalam SIMUTU

\begin{tabular}{clll}
\hline No & Jenis Evaluasi & User & \multicolumn{1}{c}{ Status Penggunaan } \\
\hline 1 & Evaluasi Pembelajaran Dosen & Mahasiswa & Aktif \\
\hline 2 & Evaluasi Layanan Perpustakaan & Mahasiswa & Aktif \\
\hline 3 & Evaluasi Layanan Perwalian Mahasiswa & Mahasiswa & Aktif \\
\hline 4 & Evaluasi Pembimbingan Tugas Akhir & Mahasiswa & Aktif \\
\hline 5 & Evaluasi Kinerja Program Studi & Admin & Tidak Aktif \\
\hline 6 & Evaluasi Kinerja Dosen & Admin & Tidak Aktif \\
\hline 7 & Evaluasi Kinerja Laboratorium & Admin & Tidak Aktif \\
\hline
\end{tabular}

KINETIK Vol. 1, No. 1, Mei 2016 : 1-8 


\section{Metode Penelitian}

Reverse engineering pada SIMUTU dilakukan dengan menggunakan pendekatan prototyping. Model prototyping memiliki fase sebagai berikut: 1) mendefinisikan kebutuhan pengguna, 2) membangun model sistem dan 3) meningkatkan fungsionalitas sistem dalam beberapa iterasi berdasarkan masukan dari pengguna [6]. Pengembangan SIMUTU model prototyping bertujuan untuk memperoleh bussines proses yang ideal dalam penyusunan instrumen evaluasi pelaksanaan standar mutu PT. Secara manual pelaksanaan tahapan evaluasi dilaksanakan sebagai berikut:
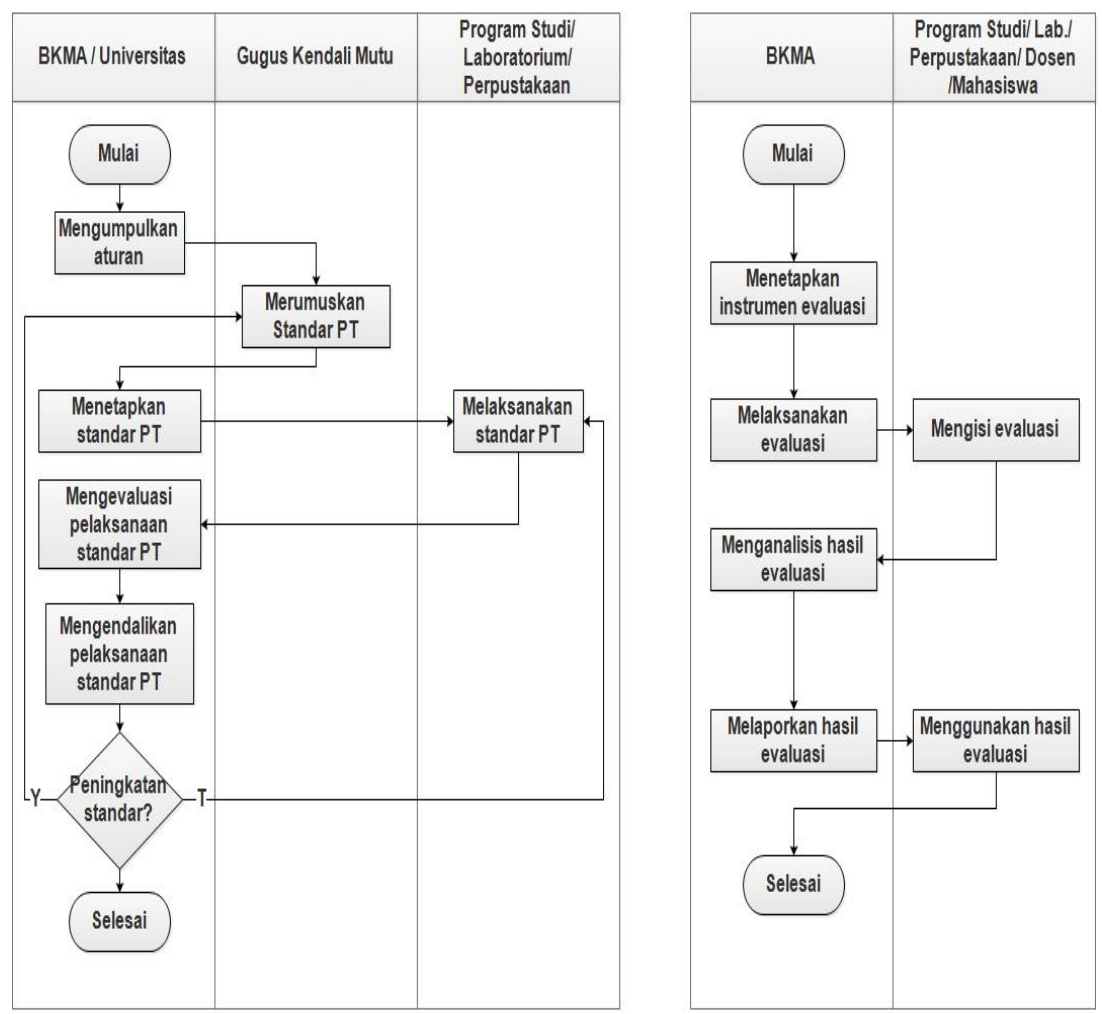

Gambar 1. kiri: Bussines process SPMI, kanan: Bussines process evaluasi pelaksanaan standar $P T$

Guna meningkatkan kualitas evaluasi, penelitian ini akan mengoptimasi prosedur pengaturan instrumen evaluasi, sehingga instrumen evaluasi dapat diubah dan ditingkatkan di setiap periode evaluasi. Selain itu, penelitian ini juga akan mengoptimasi prosedur analisis sehingga proses evaluasi menjadi lebih ringkas dan tidak membutuhkan personil analisis seperti pada pelaksanaan evaluasi secara manual. Pada akhirnya pengembangan SIMUTU akan didasarkan pada need assessment yang belum terakomodir pada SIMUTU versi 1 yang telah dibangun sebelumnya.

Mengacu pada spesifikasi SIMUTU versi 1 yang telah digunakan sebelumnya, maka penelitian ini menggunakan tahapan - tahapan pengembangan model prototyping yakni: 1) Pengumpulan kebutuhan dari berbagai pengguna sistem 2) Membangun prototype sistem 3) Uji coba dan simulasi prototype secara terbatas 4) Membangun keseluruhan sistem 5) Uji coba dan evaluasi keseluruhan sistem [5]. Pengujian SIMUTU menggunakan model automation test berbasis pengujian fungsionalitas dengan tools www.testomato.com.

\section{Hasil Penelitian dan Pembahasan}

Berdasarkan tahapan pengembangan SIMUTU dengan model prototyping, maka tahapan - tahapan tersebut sebagai berikut:

\subsection{Analisis Kebutuhan Sistem dan Aktor}

SIMUTU dioperasikan dan digunakan oleh beberapa aktor, ilustrasi fungsionalitas masing - masing aktor dapat dilihat melalui use case diagram pada Gambar 2 berikut: 


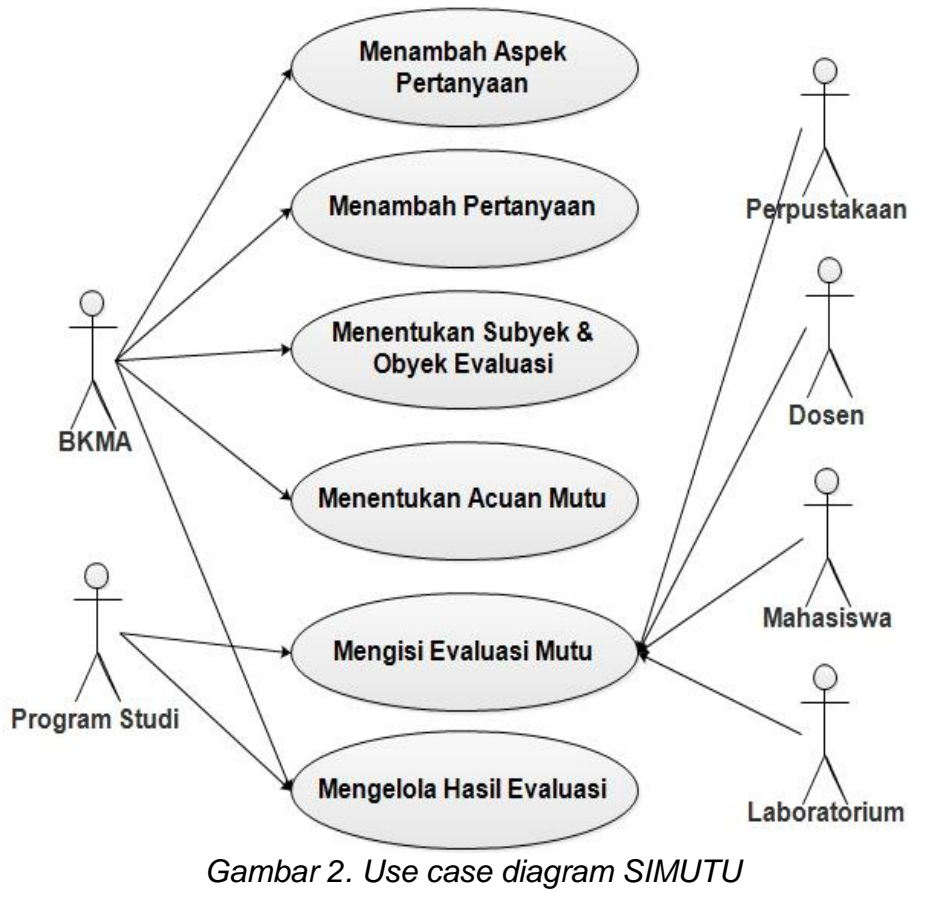

Aktor Badan Kendali Mutu Akademik (BKMA) memiliki kewenangan untuk melakukan pengaturan instrumen evaluasi. Seperti menambah aspek pertanyaan, menambah pertanyaan, menentukan subyek dan obyek evaluasi seperti mahasiswa mengevaluasi dosen, dosen mengevaluasi dirinya sendiri dan lain - lain. Aktor Program Studi memiliki fungsi selain mengisi kuisioner yakni mengelola beberapa hasil evaluasi seperti aktor BKMA. Aktor Dosen, Mahasiswa, Laboratorium dan Perpustakaan hanya mengisi evaluasi mutu yang telah ditetapkan BKMA. Analisis kebutuhan juga mensyaratkan beberapa kebutuhan data primer SIMUTU bersumber dari berbagai database, sehingga perlu dirumuskan kebutuhan data seperti pada Tabel 2.

Tabel 2. Kebutuhan data SIMUTU

\begin{tabular}{clll}
\hline No & \multicolumn{1}{c}{ Kebutuhan Data } & \multicolumn{1}{c}{ Sumber } & \multicolumn{1}{c}{ Institusi } \\
\hline 1 & Standar Mutu & Dokumen Mutu & $\begin{array}{l}\text { Badan Kendali Mutu } \\
\text { Akademik }\end{array}$ \\
\hline 2 & Akun Mahasiswa & Database Akun Mahasiswa & Infokom \\
\hline 3 & Akun Dosen & Database Akun Dosen & $\begin{array}{l}\text { Direktorat Penelitian dan } \\
\text { Pengabdian Masyarakat }\end{array}$ \\
\hline 4 & $\begin{array}{l}\text { Kegiatan Belajar } \\
\text { Mengajar }\end{array}$ & Data MAA & Biro Administrasi Akademik \\
\hline
\end{tabular}

\subsection{Pengembangan Prototype}

Prototype SIMUTU dikembangkan dengan fitur terbatas untuk aktor BKMA dan Mahasiswa. Fitur yang disediakan meliputi penyusunan instrumen evaluasi pada SIMUTU dan pengisian. Detail fitur prototype dapat dilihat pada Tabel 3.

Tabel 3. Fitur prototype

\begin{tabular}{cll}
\hline No & Aktor & \multicolumn{1}{c}{ Fitur } \\
\hline 1 & BKMA & a. Menambahkan Evaluasi Pembelajaran \\
& & b. Menentukan subyek dan obyek \\
& & evaluasi \\
& & c. Menambahkan aspek pertanyaan \\
& & d. Menambahkan pertanyaan \\
& & e. Menentukan tanggal evaluasi \\
\hline 2 & Mahasiswa & a. Mengisi Kuisioner \\
\hline
\end{tabular}

KINETIK Vol. 1, No. 1, Mei 2016 : 1-8 
Hasil perancangan dan pengembangan database prototype SIMUTU dapat dilihat pada Gambar 3. Jenis evaluasi (tabel sim_jenis_evaluasi) dibedakan berdasarkan subyek dan obyek evaluasi, untuk evaluasi pembelajaran subyek evaluasinya adalah mahasiswa, sedangkan obyek evaluasinya adalah dosen. Model kuisioner (tabel sim_model_kuisioner) dibedakan menjadi 2 model kinerja dan layanan. Untuk kebutuhan pemenuhan kaizen, aspek pertanyaan (tabel sim_aspek_pertanyaan) dan pertanyaan (tabel sim_pertanyaan) dapat di mutakhirkan setiap saat, sesuai dengan sikuls SPMI. Hasil evaluasi langsung dianalisis secara otomatis (tabel sim_hasil_ev_pembelajaran_dosen \& tabel sim_rekap_aspek_ev_Pembelajaran_dosen).

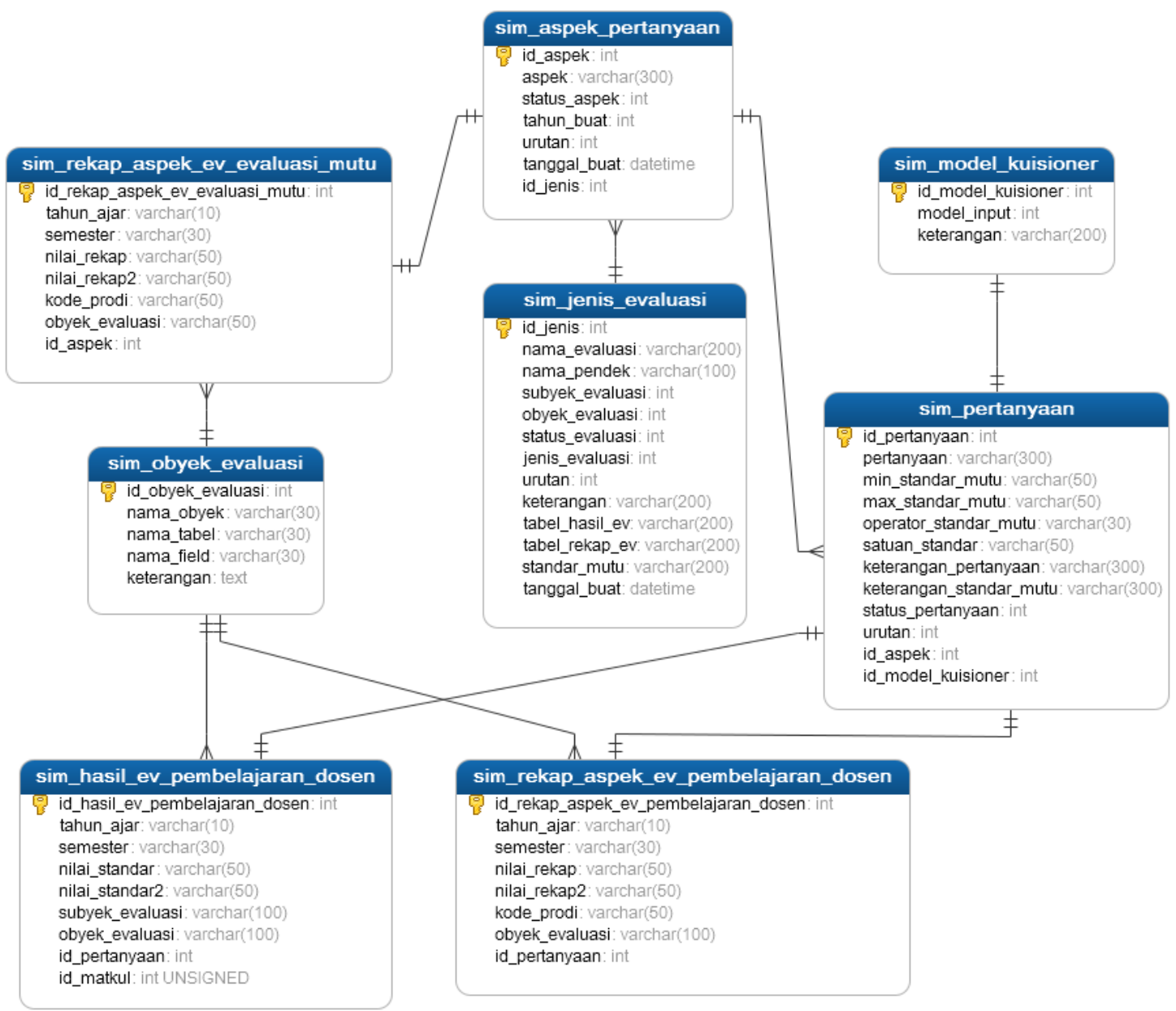

Gambar 3. Bagan Database prototype SIMUTU

Implementasi prototype SIMUTU dengan pola desain HMVC terdiri dari modul controller, model dan view. 3 class controller yakni Evaluasi, Aspek dan Pertanyaan. Masing masing class memiliki fungsi sesuai dengan kebutuhan SIMUTU, modul model terdiri dari class Mdl_evaluasi, Mdl_aspek dan Mdl_pertanyaan. Modul view terdiri berbagai macam interface untuk berbagai fungsionalitas read, update dan delete. Detail class diagram dapat dilihat pada Gambar 4.

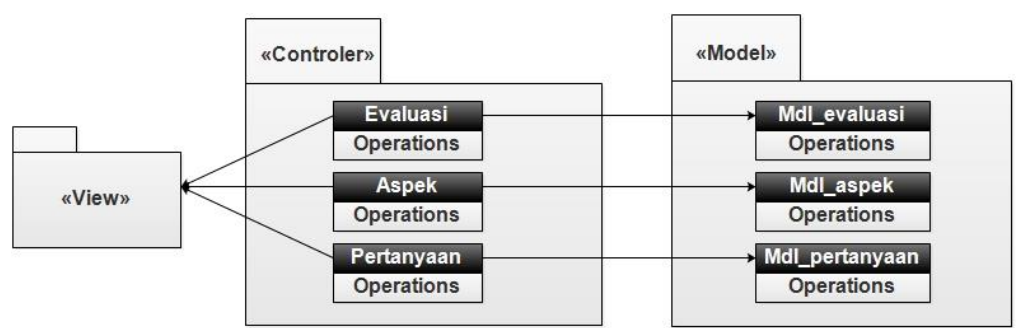

Gambar 4. Bagan class diagram prototype SIMUTU 
Sebagai ilustrasi pengaturan instrumen evaluasi melalui SIMUTU dapat dilihat pada Gambar 5. Setiap item instrumen evaluasi dapat disesuaikan dengan jenis pertanyaan yang disediakan, beberapa diantaranya seperti jenis skala nominal, skala ordinal, skala interval hingga skala likert.

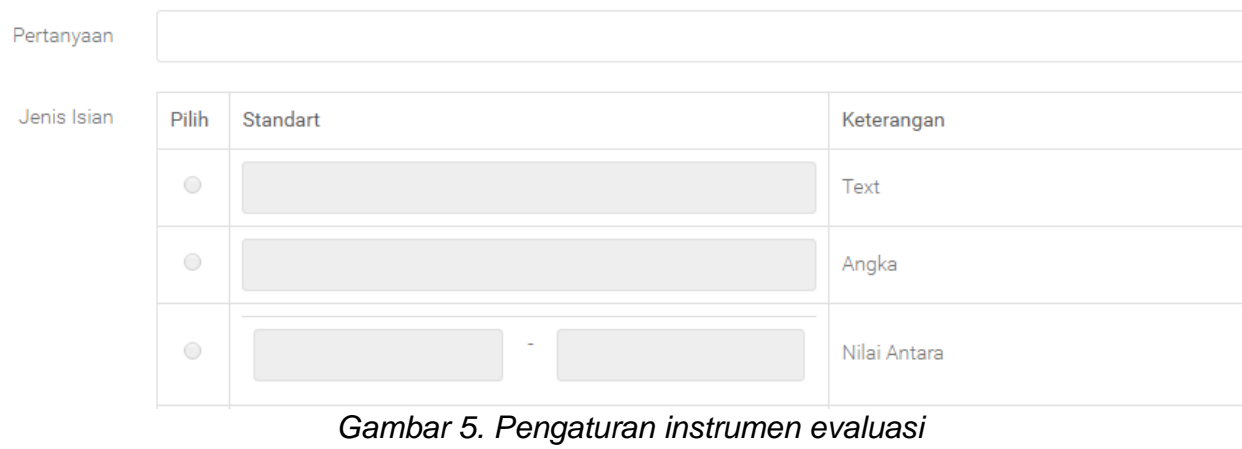

Pada halaman responden, seperti ditunjukkan pada Gambar 6, Mahasiswa disediakan antarmuka dengan pola menggeser nilai yang diinginkan dari setiap pertanyaan. Hasil evaluasi langsung dianalisis oleh sistem.
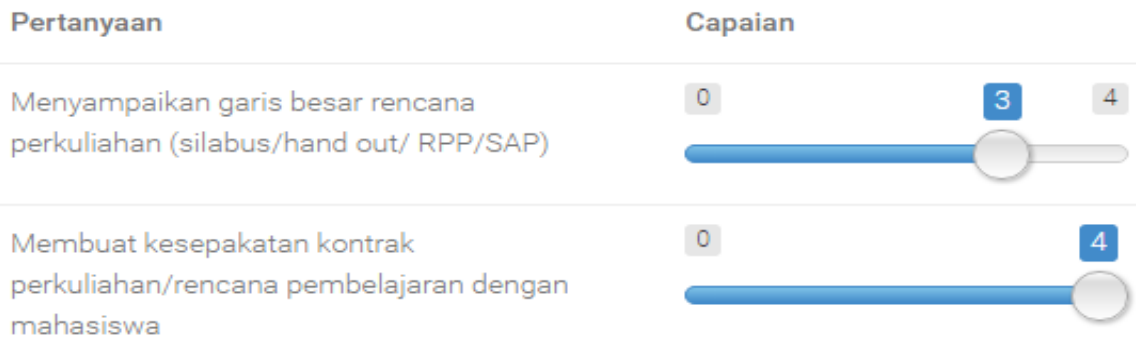

Gambar 6. Tampilan pertanyaan pada user

SIMUTU juga menyediakan rekapitulasi hasil seluruh kegiatan evaluasi, hasil rekapitulasi dapat di akses oleh aktor yang diberikan hak akses tertentu. Tampilan untuk halaman rekapitulasi diilustrasikan pada Gambar 7.

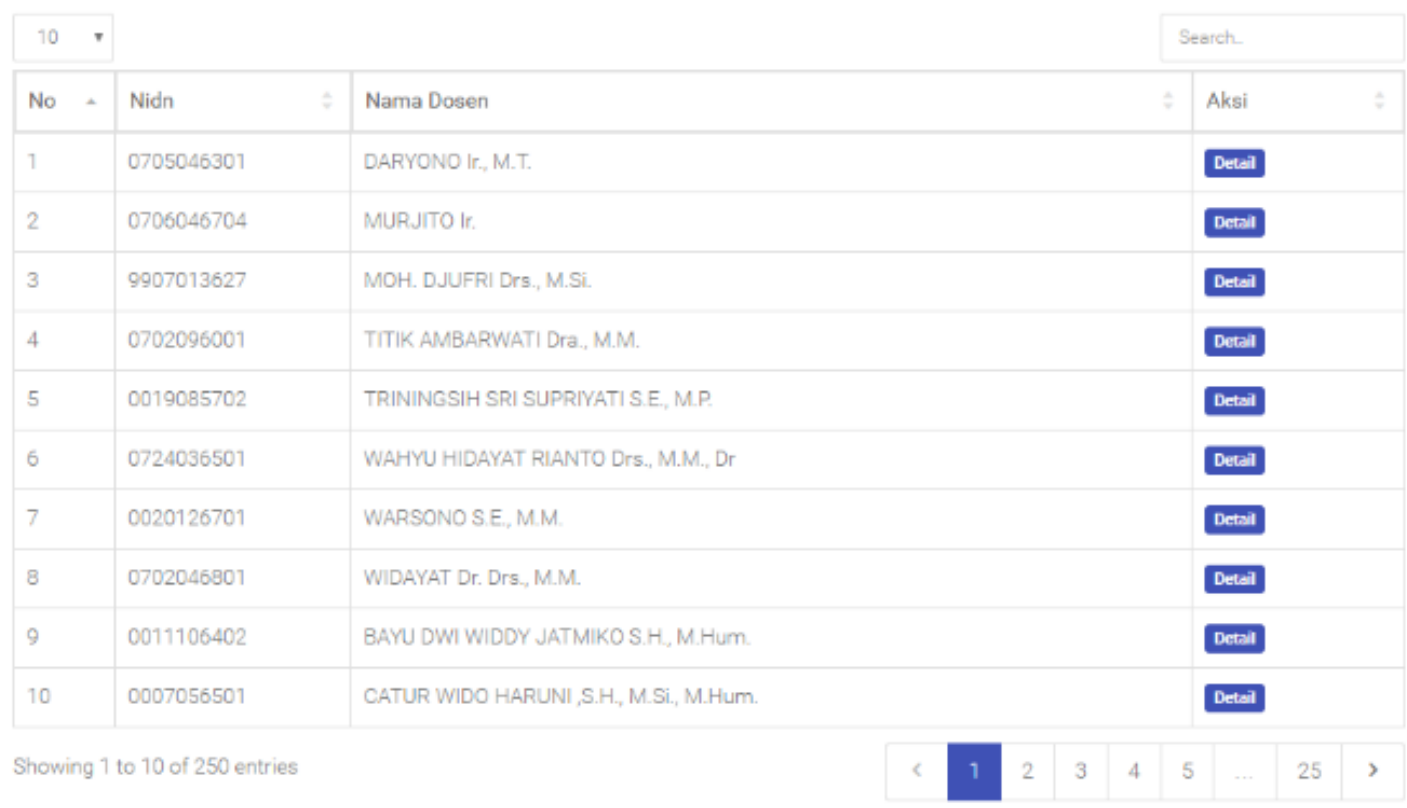

Gambar 7. Daftar evaluasi pembelajaran

KINETIK Vol. 1, No. 1, Mei 2016: 1-8 


\subsection{Uji Coba Prototype Terbatas}

Pengujian terbatas fungsionalitas prototype SIMUTU melalui website www.testomato.com diperoleh hasil semua fungsi berjalan sesuai dengan harapan, seperti pada Gambar , secara detail hasil pengujian dijelaskan pada Tabel 44.

administrator

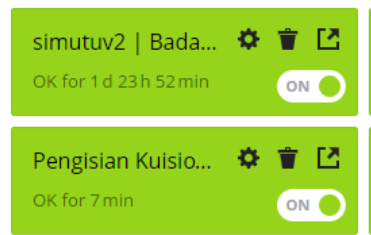

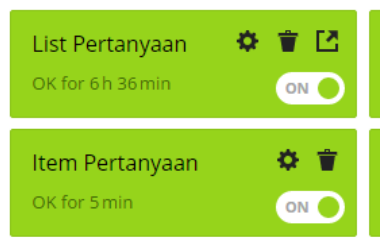
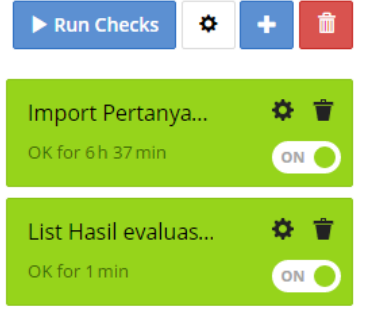

Gambar 8. Hasil pengujian fungsionalitas dengan www.testomato.com

Tabel 4. Detail hasil pengujian fungsionalitas

\begin{tabular}{lllll}
\hline No. & Pengujian & Aktor & Hasil yang diharapkan & Hasil Pengujian \\
\hline 1. & Login simutu & administrator & http equal 200(sukses) & http equal 200 \\
\hline 2. & List pertanyaan & administrator & http equal 200(sukses) & http equal 200 \\
\hline 3. & $\begin{array}{l}\text { Tambah dan import } \\
\text { pertanyaan }\end{array}$ & administrator & http equal 200(sukses) & http equal 200 \\
\hline 4. & Login pengisian simutu & mahasiswa & http equal 200(sukses) & http equal 200 \\
\hline 5. & Pengisian item instrumen & mahasiswa & http equal 200(sukses) & http equal 200 \\
\hline 6. & List hasil analisis evaluasi & administrator & http equal 200(sukses) & http equal 200 \\
\hline 7. & Hasil analisis evaluasi & administrator & http equal 200(sukses) & http equal 200 \\
\hline
\end{tabular}

Hasil pengembangan prototype SIMUTU telah mengembangkan fitur penambahan pertanyaan, analisis otomatis dan laporan hasil evaluasi pada satu jenis evaluasi, yakni evaluasi pembelajaran. Pada evaluasi tersebut subyek evaluasi adalah mahasiswa, sedangkan obyek evaluasi adalah dosen.

\subsection{Pengembangan SIMUTU}

Hasil pengembangan SIMUTU telah menyediakan 13 evaluasi mutu dijelaskan pada Tabel 5. Alamat website SIMUTU dapat diakses di http://simutu.umm.ac.id.

Tabel 5. Hasil pengembangan SIMUTU

\begin{tabular}{clll}
\hline No & Jenis Evaluasi & Subyek Evaluasi & Obyek Evaluasi \\
\hline 1 & Evaluasi Kinerja Program Studi & Program Studi & Program Studi \\
\hline 2 & Evaluasi Kinerja Perpustakaan & Perpustakaan & Perpustakaan \\
\hline 3 & Evaluasi Buku dan Sumber Belajar & Mahasiswa & Dosen \\
\hline 4 & Evaluasi Kinerja Pelayanan Perwalian Mhs & Mahasiswa & Dosen Wali \\
\hline 5 & Evaluasi Kinerja Pembimbingan Tugas Akhir & Mahasiswa & Dosen Pemb. TA \\
\hline 6 & Evaluasi Mutu Pelayanan Laboratorium & Mahasiswa & Laboratorium \\
\hline 7 & Evaluasi Mutu Pelayanan Perpustakaan & Mahasiswa & Perpustakaan \\
\hline 8 & Evaluasi Mutu Pelayanan Program Studi & Mahasiswa & Program Studi \\
\hline 9 & Evaluasi Pembelajaran & Mahasiswa & Dosen \\
\hline 10 & Evaluasi Kinerja Laboratorium & Laboratorium & Laboratorium \\
\hline 11 & Evaluasi Kinerja Dosen & Dosen & Dosen \\
\hline 12 & Evaluasi Mutu Laboratorium & Auditor BKMA & Laboratorium \\
\hline 13 & Evaluasi Ruang dan Kelengkapan & Auditor BKMA & Program Studi \\
\hline
\end{tabular}

\section{Kesimpulan}

Penelitian ini dapat mengoptimasi prosedur pengaturan instrumen evaluasi, sehingga instrumen evaluasi dapat diubah dan ditingkatkan di setiap periode evaluasi. Selain itu, penelitian ini juga akan mengoptimasi prosedur analisis sehingga proses evaluasi menjadi lebih ringkas dan tidak membutuhkan personil analisis seperti pada pelaksanaan evaluasi secara manual. Pengujian terbatas fungsionalitas pada prototype SIMUTU melalui website www.testomato.com diperoleh hasil semua fungsi berjalan sesuai dengan harapan. Hasil 
pengembangan SIMUTU secara keseluruhan berhasil menyediakan 13 evaluasi mutu dengan pengguna BKMA, Mahasiswa, Program Studi, Laboratorium, Perpustakaan dan Dosen. Alamat website dapat diakses di http://simutu.umm.ac.id.

\section{Refrensi}

[1] T. Penyusun, Pedoman Sistem Penjaminan Mutu Pendidikan Tinggi, Jakarta: Direktorat Pembelajaran dan Kemahasiswaan Direktorat Jenderal Pendidikan Tinggi, 2014.

[2] Y. Nuraeni, "Perancangan Sistem Informasi Penjaminan Mutu Perguruan Tinggi Bidang Sumber Daya Manusia," Journal of Information Systems, vol. 6, no. 1, pp. 32-43, 2010.

[3] A. Darmawan dan M. S. Hasibuan, "Analisis dan Perancangan Aplikasi Sistem Informasi Audit Mutu Internal dan Dokumentasi Penjaminan Mutu Perguruan Tinggi," Jurnal Generic, vol. 9, no. 2, pp. 342-347, 2014.

[4] Wiyana dan W. W. Winarno, "Sistem Panjaminan Mutu Pendidikan Dengan TOGAF ADM untuk Sekolah Menengah Kejuruan," Jurnal IImiah Teknologi Sistem Informasi, vol. 1, no. 1, pp. 7-14, 2015.

[5] A. Wibowo dan A. Azimah, "Rancang Bangun Sistem Informasi Penjaminan Mutu Perguruan Tinggi Menggunakan Metode Throwaway Prototyping Development," dalam Seminar Nasional Teknologi Informasi dan Multimedia, Yogyakarta, 2016.

[6] R. K. R. Jr. dan C. G. Cegielski, Introduction to Information Systems, United States of America: Wiley, 2011. 